Найдем путь шляпы за данный промежуток времени по формуле $S_{\text {ш }}=\vartheta_{\text {ш }} \cdot t$

$$
S_{ш}=3 \kappa м / ч \cdot 1 ч=3 \kappa м
$$

Найдем скорость лодки против течения по формуле $\vartheta_{\text {л }}=\vartheta_{\text {лс }}-\vartheta_{\text {т }}$

$$
\vartheta_{л}=8 \frac{\kappa M}{ч}-3 \frac{\kappa M}{ч}=5 \kappa M / ч
$$

Найдем путь лодки за данный промежуток времени по формуле $S_{\text {л }}=\vartheta_{\text {л }} \cdot t$

$$
S_{\text {Л }}=5 \frac{\mathrm{KM}}{ч} \cdot 1 ч=5 \text { км }
$$

Найдем расстояние между шляпой и лодкой через данный промежуток времени по формуле

$$
\begin{gathered}
S=S_{\text {ш }}+S_{\text {л }} \\
S=3 \text { км }+5 \text { км }=8 \text { км }
\end{gathered}
$$

5. Проверка решения задачи: Полученное расстояние 8 км разделим на время движения 1 ч и получим скорость удаления шляпы и лодки друг от друга -8 км/ч (3 км/ч +5 км/ч), что полностью совпадает с решением задачи.

6. Ответ: $S=8$ км.

7. Анализ решения задачи: мы свели решение этой задачи к выполнению четырех простейших арифметических действий, что сильно упрощает задачу и наглядно демонстрирует происходящие в ней действия. Но ее можно было решить немного короче ввиду того, что можно было бы изначально найти скорость удаления объектов и затем эту скорость умножить на время их удаления, но тогда у слабых учащихся могут возникнуть вопросы по этому поводу. В решенной задаче основу решения составляет графическое изображение. Это говорит о том, что формируется графическая культура школьников, как часть математической культуры.

\section{Заключение}

Простота в изображении, безусловно, помогает учащимся лучше разобраться с тем, что происходит в задаче и что в ней требуется найти, а это уже находит свое отражение при формировании математической культуры, поскольку математическая культура - это, прежде всего, умение описывать происходящее вокруг (в данном случае происходящее в задаче) математическими методами. На основе рассмотренной теории и разобранных примеров можно сделать вывод о том, что наглядное моделирование и различные ее виды являются основным элементом при формировании у учащихся математической грамотности и математической культуры. В дальнейшем это позволит в каждой теме курса математики 5-6 классов, в любой ситуации, в каждой решаемой задаче сформировать наглядные образы изучаемых понятий и объектов и использовать их при обучении школьников.

\section{СПИСОК ЛИТЕРАТУРЫ}

1. Никольский С.M., Потапов М.К., Решетников Н.Н., Шевкин А.В., Математика, 5 класс - М.: Просвещение, 2018.

2. Зубарева И. И., Мордкович А. Г., Математика, 5 класс. - М. : Мнемозина, 2009.

3. Малыхина В. В. Методика формирования у младших школьников умения решать текстовые задачи в системе развивающего обучения: Дисс.. канд. пед. наук. - М., Просвещение, 1996.

4. Шихалиев X. Ш. Каким должен быть школьный курс математики // Математика в школе, 2003 №2.

5. Ефимов В. Ф. Формирование вычислительной культуры младших школьников // Начальная школа. - 2014. - № 1. - С.28-32., с. 30.

6. Уртенова А. У., Уртенов Н. С. Математическая культура: структура и содержание // Сибирский педагогический журнал. 2014. №2. URL:

https://cyberleninka.ru/article/n/matematicheskayakultura-struktura-i-soderzhanie (дата обращения: 22.07.2020)

7. https://fgos.ru/.

\title{
CONTROL OF THE ELECTRON BEAM DEFLECTION SYSTEM OF AN ELECTRON BEAM
} INSTALLATION

\section{ABSTRACT}

Volodya Dzharov ${ }^{1}$

1 - Institute of Electronics, Bulgarian Academy of Sciences, 72, Tzarigradsko shose, Sofia 1784, Bulgaria DOI: 10.31618/ESU.2413-9335.2020.2.76.900

This paper explores patterns of electronic beam movement by controlling the transverse axis of the bundle of the uniform magnetic field generated by the coils of the electronic gun. For electron beam processes, the type of process, the technological mode, the design dimensions of the electronic gun, and the shape of the machined parts determines beam motion. The free and precise movement on random trajectories determines the possible applications of the electron beam process in performing various scientific experiments on material processing.

\section{Introduction}

Electron Beam Welding (EBW) is a modern method for the creation of non-dismountable compounds by local melting and solidification of the material widely applied in industrially industrialized countries [1]. In the present work is presented the work of the diverting system of electron beam welding gun. 


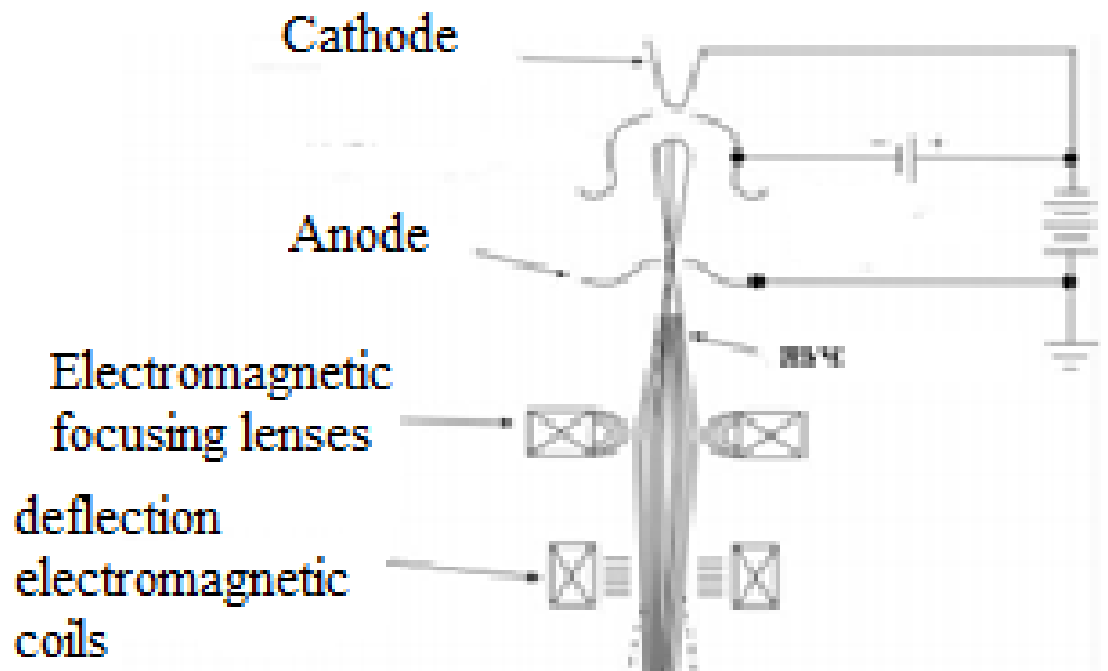

beam deflection

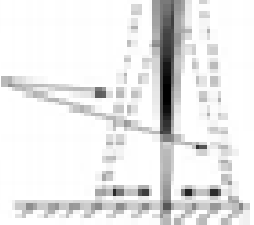

Figure 1. Electronic-optical circuit of a gun for electronic welding. [2]

EBW is carried out by an Electronic Gun (Figure 1 ) in which the electron beam is formed. From the high voltage source, electrons are fed to the cathode, which passes through the anode to form a beam, the main components of which are voltage and current of the beam. The electron beam is controlled by electromagnetic focusing lenses and four $90^{\circ}$ divergent electromagnetic coils.

\section{Setting the task.}

Magnetism - a section of physics that studies one of the main interactions in nature - the interaction between moving electric charges, called magnetic interaction. Similar to electric forces and magnetic forces acting on the magnetic forces, they also have their own mediator - the magnetic field. The magnetic field of constant currents is inextricably linked to the existence of currents. Two wires that run parallel to each other are electrically connected or repulsed depending on the direction of the current in the wires. With this experience in 1820, André-Marie Ampere formulated Amper's so-called law. According to Amper, the field of the so-called magnets is created by elementary (micro) currents in the magnets generated by the electrons moving around the nuclei of the atoms. Around every moving electric charge or electric current there are always two fields - electric and magnetic. The induction of the magnetic field is a Tesla (T) when it acts with magnetic force a Newton $(\mathrm{N})$ on a conductor with a length of one meter $(\mathrm{m})$ on which one Ampere (A) current flows:

$$
1 T=\frac{1 N}{A * m}
$$

The electrostatic field is inextricably linked to the existence of electrical charges. Therefore, there is a magnetic field or electrostatic field in the space if there are electric currents or electric charges and absent if, they are not. The current flowing on the windings can control the magnetic field of the electromagnet. The understanding of the magnetic field is built into two positions: the moving charges create a magnetic field and the magnetic field acts on the moving charges. The force with which the magnetic field acts on moving charges is called the strength of Lorentz. 


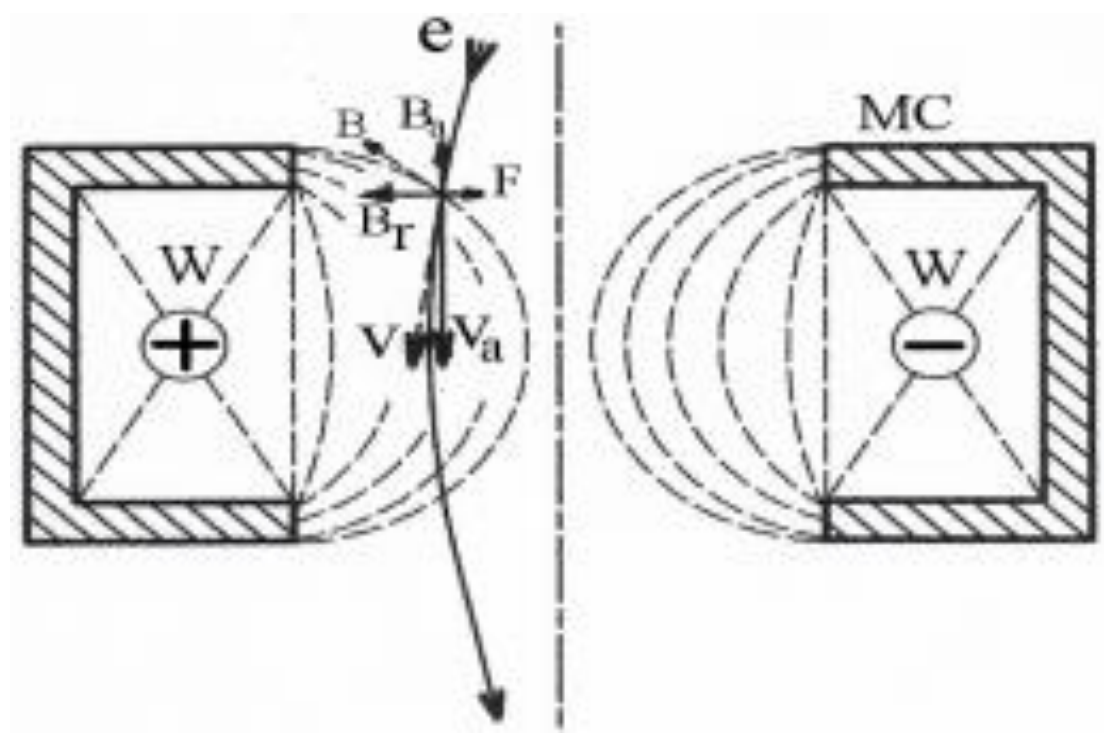

Figure 2. Magnetic lens

Figure 2 shows the operation of a magnetic lens that diverts the electrons forming the beam in different directions depending on the difference in the supply current of the windings of the diverting coils.
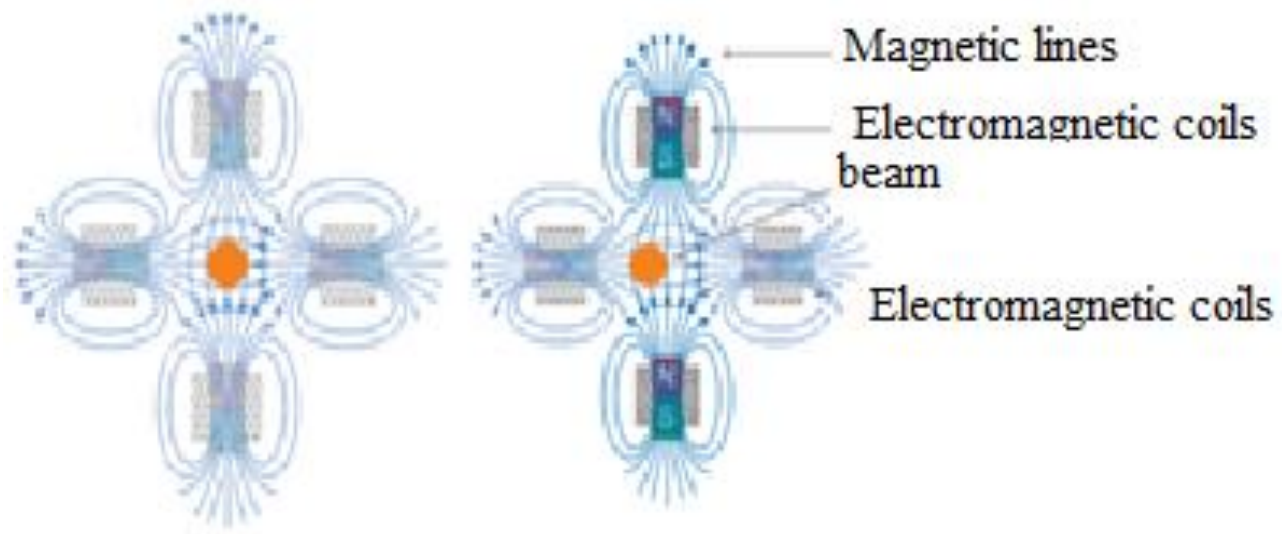

Figure 3. In a homogeneous magnetic field perpendicular to an electron beam, the originally centered beam (left) diverges laterally (right). [5]

Magnetic field is created by moving electric charges (currents). In order to determine the direction of the induction vector of the magnetic field in a conductor with current, the drilling rule or the right hand rule. The magnetic diverting system is used to control the beam by guiding it through the cuts of the welded articles. By arranging two windings perpendicular to the light, conditionally in the shape of a cylinder of diameter $d$, creating a magnetic field similar to the magnet horseshoe, the electron beam can be deflected laterally. They can be used for "static" or "dynamic" deviation. Static deflection is useful for accurate beam positioning when welding. The dynamic deviation is realized by powering the deflector coils with computer-controlled currents. The number of turns of the diverting coils required to deflect the energy beam of the electrons $U$ at an angle $\theta$ is determined by the ratio:

$$
(I W)_{d e v}=2.65 \frac{d \sqrt{U}}{l} \sin \theta ;
$$

where 1-width, mm;
For example, for coils with internal diameter $\mathrm{d}=60 \mathrm{~mm}$ and width $1=60 \mathrm{~mm}$ with electron energy $50 \mathrm{kV}$, the maximum beam bias of $\theta=15^{\circ}$ will be reached at $(\mathrm{IW})=160$ shifts. Coil windings are distributed so that the system creates a homogeneous magnetic field capable of deflecting the beam without changing its shape.

The ratio defining the angle of deflection of the beam:

$$
I_{\text {def }}=k_{3} \sqrt{U} \sin \theta
$$

where:

$I_{\text {def }}$ - current of the diverting system;

$\mathrm{k}_{3}-$ Proportionality factor $=\frac{\mu_{0}}{4 \pi}$;

$\mu_{0}$ - magnetic constant;

$\mathrm{U}$ - voltage;

$\theta$ - angle of deflection of the beam relative to the axes of the electronic optical system;

By supplying a certain current and voltage to the deflection system, we can determine by the angle of deviation $\theta$ at what distance the beam can deflect. In the experimental part of this article, the formula for the 
deflection current is calculated for specific currents and the acceleration voltage at what angle and at what distance it will deflect the beam. The distance will change from a manipulator located in the vacuum chamber.

\begin{tabular}{|c|c|c|c|c|c|}
\hline $\mathrm{g}$ & $\mathrm{U}$ & $\mathrm{I}_{\text {def }}$ & $\mathrm{K}_{3}$ & $\theta^{\circ}$ & TEF, $\mathrm{mm}$ \\
\hline 340 & 50 & 40 & 2 & $-0,04967$ & $-16,9005$ \\
\hline 340 & 50 & 50 & 2 & 0,749633 & 316,5095 \\
\hline 340 & 50 & 60 & 2 & $-0,99722$ & $-526,299$ \\
\hline 340 & 50 & 70 & 2 & 0,643029 & 254,749 \\
\hline 340 & 50 & 80 & 2 & 0,09921 & 33,84257 \\
\hline 340 & 50 & 90 & 2 & $-0,78158$ & $-337,413$ \\
\hline 340 & 50 & 100 & 2 & 0,992295 & 520,651 \\
\hline
\end{tabular}

Figure 4 shows a graph of the deviation of the beam welding point positions indicated in Table 1.

\section{Experimental part}

In Table $1 \mathrm{U}=50 \mathrm{kV}$, the current supplied to the coils $\mathrm{I}_{\mathrm{def}}=40 \div 100 \mathrm{~mA}$, the beam length $\mathrm{z}=340 \mathrm{~mm}$ :

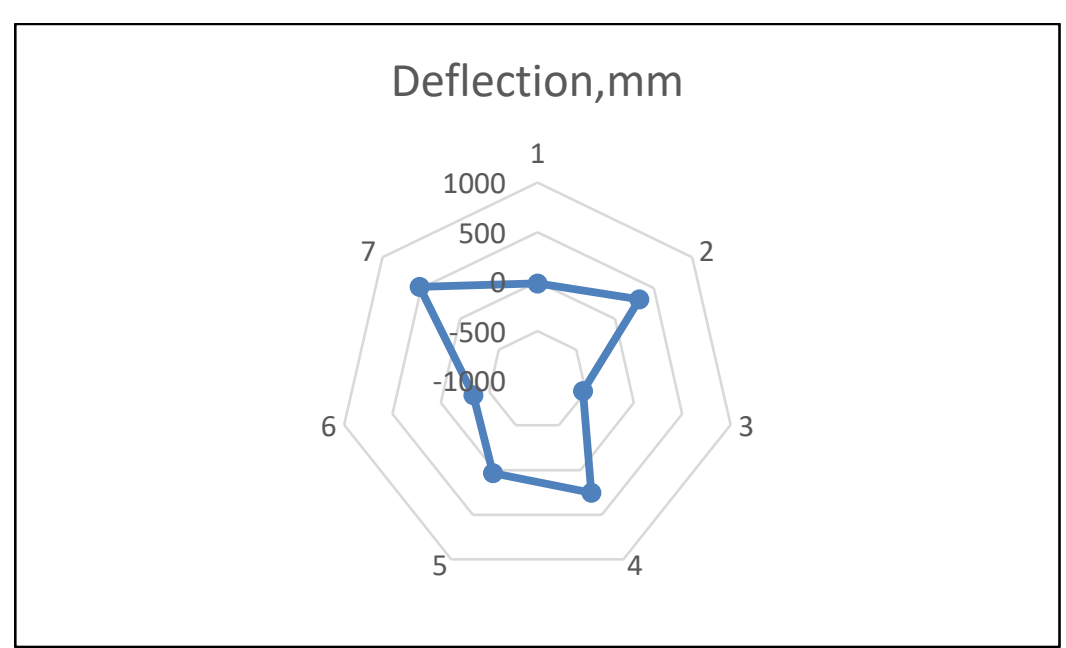

Figure four Deviation of the beam with current and voltage parameters

In Table $2 \mathrm{U}=150 \mathrm{kV}$, the current supplied to the coils $\mathrm{I}_{\text {def }}=40 \div 100 \mathrm{~mA}$, the beam length $\mathrm{z}=300 \mathrm{~mm}$ :

Table 2

\begin{tabular}{|c|c|c|c|c|c|}
\hline$z$ & $\mathrm{U}$ & $\mathrm{I}_{\text {def }}$ & $\mathrm{K}_{3}$ & $\theta^{\text {o }}$ & DEF,mm \\
\hline 300 & 150 & 40 & 2 & $-0,09511$ & $-28,619$ \\
\hline 300 & 150 & 50 & 2 & $-0,99292$ & $-460,026$ \\
\hline 300 & 150 & 60 & 2 & 0,142393 & 43,0091 \\
\hline 300 & 150 & 70 & 2 & 0,986139 & 453,2781 \\
\hline 300 & 150 & 80 & 2 & $-0,18936$ & $-57,4954$ \\
\hline 300 & 150 & 90 & 2 & $-0,97712$ & $-444,516$ \\
\hline 300 & 150 & 100 & 2 & 0,235888 & 72,10869 \\
\hline
\end{tabular}

Figure 5 shows a graph of the deviation of the beam welding point positions as shown in Table 2 . 


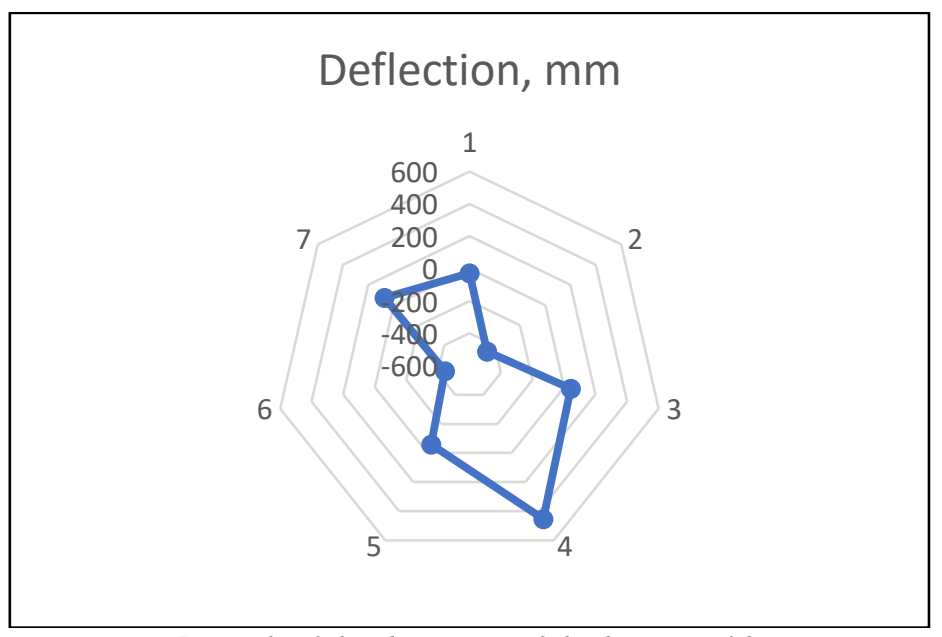

Figure 5 graph of the deviation of the beam welding point

By changing the parameters of the currents and voltages supplied to the electromagnetic coils, we can divert the beam in the desired direction depending on the welded product. Another parameter that can be changed is the focal length by changing the height and position of the product via a PLC or microPLC controlled handler.

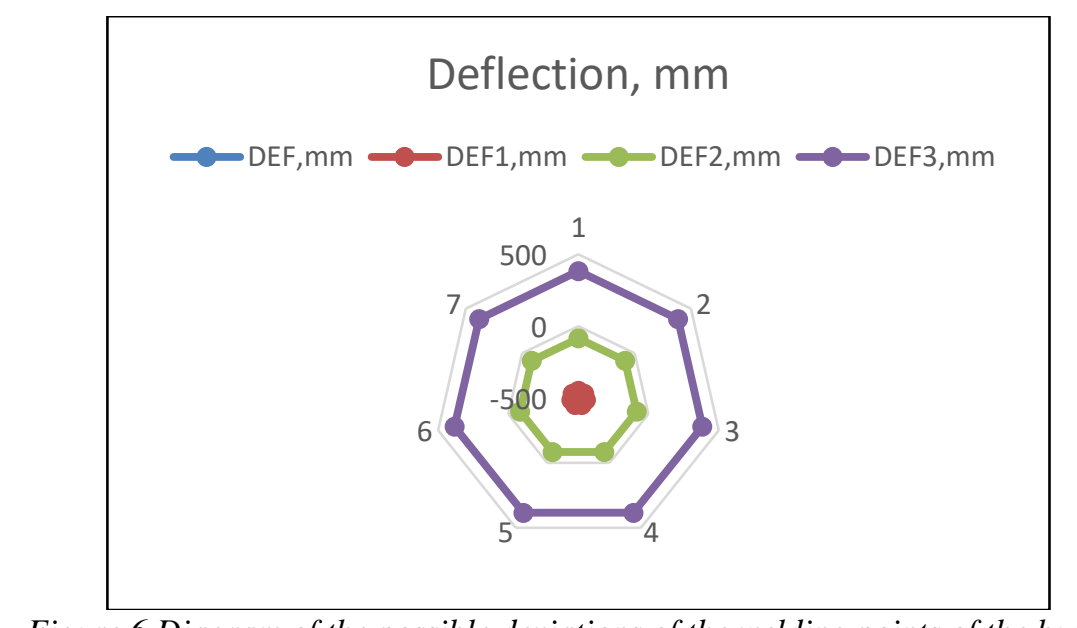

Figure 6 Diagram of the possible deviations of the welding points of the bundle

For the control of the EG diversion system located in IE-BAS will be used PLS SIEMENS, which will supply a control signal to the diverting coils. When welding checks are carried out, a computerized measurement information system based on a compatible computer equipped with an MPI interface connected to PLS SIEMENS is used to record the current passing through the collector circuit. The saved results will be stored in a file for further processing.

4. Conclusion:

In the presented work a simulation is made and the possibility for deflection of the electron beam by changing the current applied to the deflection windings of the electromagnetic coils located in the electron beam gun is empirically shown.

5. Acknowledgments:

The author thanks for the support provided by the NATIONAL PROGRAM "YOUNG SCIENTISTS AND POSTDOCTRANTS" funded by the Ministry of Education and Science

\section{LITERATURE:}

1.Младенов Г., Електронни и йонни технологии, изд. „Проф. Марин Дринов”, 2009 г.
2.Experience on electron beam welding, E.G. Koleva and G.M Mladenov, Institute of Electronics, Bulgarian Academy of Sciences, Practical Aspects and Applications of Electron Beam Irradiation, 2011: 95133, ISBN: 978-81-7895-541-4;

3. Statistical modelling and computer programs for optimisation of the electron beam welding of stainless steel, Elena Koleva, Institute of Electronics, Bulgarian Academy of Sciences, 72, boul. Tzarigradsko shossee, Soxa 1784, Bulgaria, Vacuum 62 (2001) 151$\} 157$

4. Plasma Charge Current for Controlling and Monitoring Electron Beam Welding with Beam Oscillation, Dmitriy Trushnikov, Vladimir Belenkiy, Valeriy Shchavlev, Anatoliy Piskunov, Aleksandr Abdullin, and Georgy Mladenov, Sensors (Basel). 2012 Dec; 12(12): 17433-17445.Published online 2012 Dec 14. doi: 10.3390/s121217433;

5. Electron Beam Welding, The fundamentals of a fascinating technology, Volker Adam, Uwe Clauß, Dr. h. c. Dietrich v. Dobeneck, Dr. Thomas Krüssel, Dr. Thorsten Löwer, Publisher: pro-beam AG \& Co. KGaA, www.pro-beam.com 
6. Оборудване для электронно-лучевой сварки, А.И. Чвертко, О.К.. Назаренко, А.М. Святский,

А.И. Некрасов, Издателство”Наукова думка", Киев-1973 г.

УДК 621.382

ГРНТИ 29.35.47. Твердотельные приборы СВЧ-диапазона.

\title{
МОДЕЛИРОВАНИЕ ПАРАЗИТНЫХ ТУННЕЛЬНЫХ ТОКОВ В ЭЛЕМЕНТАХ ФЛЕШ-ПАМЯТИ НА ОСНОВЕ КОРОТКОКАНАЛЬНЫХ МОП-ТРАНЗИСТОРОВ
}

\author{
Жевняк Олег Григорьевич. \\ Белорусский государственный университет, \\ Минск, Республика Беларусь, 220030, пр. Независимости,4.
}

Zhevnyak Oleg Grygoryevich. DOI: 10.31618/ESU.2413-9335.2020.2.76.901

\section{АННОТАЦИЯ}

Моделирование паразитных туннельных токов в элементах флеш-памяти на основе короткоканальных МОП-транзисторов.

В настоящей работе с помощью численного моделирования методом Монте-Карло электронного переноса в короткоканальных МОП-транзисторах с плавающим затвором рассчитаны распределения величины паразитного туннельного тока и средних значений энергии и подвижности электронов вдоль проводящего канала этих транзисторов. Проанализировано влияние стокового напряжения в элементах флеш-памяти при считывании информации в них на данные распределения. Показано, что в целом для рабочих режимов величина паразитных токов в рассмотренных элементах флеш-памяти очень мала. Однако при длительном хранении она может привести к изменению хранящегося на плавающем затворе заряда.

\section{ABSTRACT}

Simulation of parasitic currents in Flash-memory cells based on short-channel MOSFET.

In present paper the distributions of parasitic tunneling current as well as mean electron energy and mobility along the channel are calculated for short-channel MOSFETs by using Monte Carlo simulation of electron drift in such devices. The effect of drain bias in Flash-memory cells on these distributions is investigated for reading information regime. It is shown that the value of parasitic current is very small at considered conditions. But long storage can be change the charge in a floating gate of short-channel MOSFETs.

Ключевые слова: флеш-память, короткоканальный МОП-транзистор, туннелирование электронов, дрейф электронов, метод Монте-Карло.

Key words: Flash-memory, short-channel MOSFETs, electron tunneling, electron drift, Monte Carlo simulation.

Тенденции развития современных технологий флеш-памяти на основе кремниевых МОПтранзисторов с плавающими затворами направлены на уменьшение размеров данных транзисторов и повышение надёжности хранения информации в них, т. е. снижение величины протекающих в этих транзисторах паразитных туннельных токов (см., например, [1; 2]). Туннельные токи порождаются неоднородностями электронной плотности и электрического потенциала, возникающими в проводящем канале короткоканальных кремниевых МОП-транзисторов, лежащих в основе ячеек флешпамяти, при чтении хранящейся в них информации. Накопление электронов с достаточно высокими энергиями в определенных участках канала может приводить к нежелательному туннелированию этих электронов на плавающий затвор и искажению хранящейся на нем информации.

Целью настоящего исследования явилось моделирование паразитных туннельных токов в короткоканальных МОП-транзисторах с плавающим затвором и, в частности, оценка влияния на них величины стокового напряжения транзистора при возможных режимах считывания хранящейся в ячейке флеш-памяти информации.
Расчет туннельных токов осуществлялся на основе моделирования электронного переноса в канале МОП-транзистора методом Монте-Карло вместе с самосогласованным решением уравнения Пуассона. Алгоритмы такого моделирования приведены в работах [3; 4], а процедура расчета туннельного тока рассмотрена в работе [5]. В качестве модельного исследовался МОПтранзистор с плавающим затвором со следующими конструктивно-технологическими параметрами:

длина канала $L_{c h}=0,15$ мкм, толщина подзатворного окисла $d_{\text {окс }}=6 \mathrm{HM}$, толщина туннельного окисла $d_{\text {тун }}=2 \mathrm{HM}$, толщина плавающего затвора $d_{\text {плав }}=2 \mathrm{Hм}$, концентрация донорной примеси в областях истока и стока $N_{D}=10^{26} \mathrm{M}^{-3}$, концентрация акцепторной примеси в подложке $N_{A}=10^{24} \mathrm{M}^{-3}$, глубина залегания истоковой и стоковой областей в подложку $d_{j}=100 \mathrm{HM}$.

На рис. 1 приведена энергетическая диаграмма ячейки флеш-памяти при протекании в ней паразитных туннельных токов. При считывании информации подаются рабочие напряжения на сток и затвор (порядка $2 \mathrm{~B}$ ). Величина $U_{\text {тун }}$ относительна невелика (составляет около $0,3 \div 0,4$ от $\left.U_{\text {затв}}\right)$, и 